\title{
Protein structure of the venom in nine species of snake: from bio-compounds to possible healing agents
}

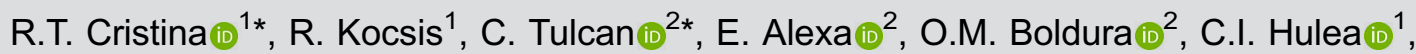 \\ E. Dumitrescu (10) ${ }^{1}$, I. Radulov (10) ${ }^{3}$, and F. Muselin (10) \\ ${ }^{1}$ Department of Pharmacology and Pharmacy, Faculty of Veterinary Medicine, Banat's University of Agricultural Sciences and \\ Veterinary Medicine "King Michael I of Romania" from Timișoara, Timișoara, Romania \\ ${ }^{2}$ Department of Biochemistry, Faculty of Veterinary Medicine, Banat's University of Agricultural Sciences and Veterinary Medicine \\ "King Michael I of Romania" from Timișoara, Timișoara, Romania \\ ${ }^{3}$ Department of Chemistry, Faculty of Agriculture, Banat's University of Agricultural Sciences and Veterinary Medicine \\ "King Michael I of Romania" from Timișoara, Timișoara, Romania \\ ${ }^{4}$ Department of Toxicology, Faculty of Veterinary Medicine, Banat's University of Agriculture and Veterinary Medicine \\ "King Michael I of Romania" from Timișoara, Timișoara, Romania
}

\begin{abstract}
Due to its various structures in bio-compounds, snake venom is the indisputable result of evolutionary stages of molecules with an increasingly complex structure, high specificity, and of great importance for medicine because of their potential. The present study proposed an underpinning examination of venom composition from nine species of venomous snakes using a useful and replicable methodology. The objective was the extension of the evaluation of protein fractions in the field up to $230 \mathrm{kDa}$ to permit possible identification of some fractions that are insufficiently studied. The gel capillary electrophoresis method on the chip was performed using an Agilent 2100 bioassay with the 80 and 230-LabChip Protein kits. Interpretation of electrophoresis was performed using the Protein 2100 expert (Agilent) test software as follows: a) Protein 80 (peak size scale): 1.60, 3.5, 6.50, $15.00,28.00,46.00,63.00,95.00 \mathrm{kDa}$; b) Protein 230 (peak size scale): 4.50, 7.00, 15.00, 28.00, 46.00, 63.00, 95.00, 150.00, $240.00 \mathrm{kDa}$. The screening revealed the presence of compounds with a molecular weight greater than $80 \mathrm{kDa}$, in the case of Vipera aspis and Vipera xantina palestinae. For V. aspis, a $125 \mathrm{kDa}$ molecular weight pro-coagulant protein was identified, known as being involved in the reduction of plasma clotting time without any direct activity in the fibrinogen coagulation process. The samples examined on the Protein 230-LabChip electrophoresis chip can be considered as a novelty with possible uses in medicine, requiring further approaches by advanced proteomics techniques to confirm the intimate structural features and biological properties of snake venoms.
\end{abstract}

Key words: Bio-compounds; Protein LabChip; Venomics; Vipera aspis; V. xantina palestinae

\section{Introduction}

Due to the various structures of bio-compounds (e.g., peptides, toxins, enzymes, up to 100 proteins, and different isoforms), snake venoms are the indisputable result of evolutionary stages for molecules with an increasingly complex structure and high specificity (1-3).

This high protein amino acid abundance, generally possessing specific enzymatic and polypeptide characteristics, is often different from one snake species to another, but authors generally agree that these assemblies can be classified into several common chemical families like: phosphodiesterases (4), acetylcholinesterases (5), phospholipases $(6,7)$, proteases (serine and metalloproteases) (8-10), disintegrins $(11,12)$, as well as the so-called "threefinger toxins" tri-toxins: neuro-cardio-hemodyotoxins (13). Certainly, this large blend of biochemical molecules present in snake venoms makes these various and complex structures attractive to the investigation of new therapeutic resources $(14,15)$.

Venom components are recognized as effective in the treatment of blood pathology, mainly in hemostasis

Correspondence: R.T. Cristina: <rtcristina@yahoo.com > | C. Tulcan <tulcancamelia@gmail.com>

${ }^{*}$ These authors contributed equally to this work.

Received June 27, 2019| Accepted October 31, 2019 
and anticoagulation/coagulation processes (16-18), in hypertension, influencing angiotensin-converting enzyme inhibitors, or in renal disease (19).

Also, the disintegrins in the venom have been shown to be integrin modulators, with definite anti-tumor, metastatic, or anti-angiogenic activity (20-22). These new activities were also studied for possible treatments of arthritis and thrombosis (22).

Knowing that snake venom contains a very wide range of biological structures, studies of structure identification and biological and pharmaco-clinical activity are now of great importance. In this context, the present study proposed an examination of venom composition from nine species of venomous snakes belonging to the Viperidae and Crotalinae genus using a useful and replicable methodology.

The extension of protein fractions evaluation in the field up to $230 \mathrm{kDa}$ allows the identification of fractions that are insufficiently studied so far, including both their structures and their biological effects.

\section{Material and Methods}

\section{Venom collection}

In all cases, animal manipulation, including snakes' harvesting, was in line with the UNC Institutional Animal Care and Use Committee approved protocols, and none of the animals were on the International Union for Conservation of Nature threatened species list.

Fresh venom samples were obtained from nine different species of snakes. The person responsible for the venom gathering was an expert in exotic pathology, the owner of a specialized exotic animals clinic, and a certified veterinarian in snake venom collection. The samples were gathered from pet snakes living in home terrariums and usually registered and treated in this clinic. For venom collection, the classical technique from the literature was used $(23,24)$.

After sampling, the venom was air-dried and the samples stored in a crystalline state in a freezer at $-80 \pm 2^{\circ} \mathrm{C}$ until the chemical analysis was performed (25).

\section{Reagents and equipment used}

The reagents used were: bovine serum albumin (BSA) (Sigma Aldrich, Germany), Folin Ciocalteu reagent (Merck, Germany), $\mathrm{Na}_{2} \mathrm{CO}_{3}, \mathrm{NaOH}, \mathrm{Na}_{2}$-tartrate $\times 2 \mathrm{H}_{2} \mathrm{O}$, all analytical grades (Merck), ultrapure water (Waters Millipore, Germany).

The equipment used for sample preparation and analyses were: analytical scale Kern EG 420-3NM (Germany), Hettich Universal-320R centrifuge (Germany), IKA-4 digital Vortex centrifuge (Germany), Agilent 2100 bioanalyzer (USA), MilliQ integral 5 Pure System - Ultrapure Water Station (Germany), and Thermo Scientific 902 ultra-freezer (USA). Chromatographic analysis was performed on a Perkin Elmer - Lambda 25 spectrophotometer (USA).

\section{Freeze drying methodology}

The working procedure included: weighing the initially crystallized venom, solubilization of crystalline venom, rapid freeze-drying, preparing the ampoules, homogenizing the final product, and final weighing. The lyophilizer used in our experiment was one Ilshin Kryptonstraat 11_6718_WR_EDE (Ilshin, The Netherlands) with the following parameters: freeze-drying: $-54^{\circ} \mathrm{C}, 5 \mathrm{mTorr}$ for $48 \mathrm{~h}$; freezing yield was between $76.80-89.16 \%$.

\section{Validation method}

Validation was done by the determination of the solid substance, according to the known standardized method at $103^{\circ} \mathrm{C}$. The ampoule with the sample was kept for $12 \mathrm{~h}$ at $103^{\circ} \mathrm{C}$. The vial was then inserted into the dryer for cooling. After cooling, the vial was weighed with an accuracy of $0.0001 \mathrm{~g}$. The heating operation was repeated for one hour, cooling and weighing until the results obtained on two successive weighing did not differ by more than $0.1 \%$. The results were compared with freeze-dried venom water content in order to optimize the freezedrying conditions. The freeze-drying yield was calculated as a percentage of the dry matter obtained by comparison with the initial amount contained therein. The samples were lyophilized and stored in the freezer at $-80^{\circ} \mathrm{C}$ in Eppendorf tubes and sealed with paraffin foil to prevent wetting of the samples, according to WHO Guidelines (2016) for the Production, Control and Regulation of Snake Antivenom Immunoglobulins (https://www.who.int/ biologicals/expert_committee/Antivenom_WHO_Guidelines_ DJW_DEB_mn_cp.pdf?ua\%20=\%201).

\section{Gel capillary electrophoresis (CGE) on laser-induced fluorescence detection chip}

The CGE method on chip was performed using an Agilent 2100 bioassay (Agilent Technologies, Germany) with the 80-LabChip Protein and 230-LabChip Protein kits, according to the protocol described by the manufacturer and following the methodology described by Halassy et al. (26).

Prior to electrophoresis, the samples were diluted in $30 \mathrm{mM}$ Tris/ $\mathrm{HCl}$ at $\mathrm{pH} 8.5$ to a concentration of $10 \mathrm{mg} / \mathrm{mL}$ ( $4 \mu \mathrm{L}$ of the diluted samples of each type of venom were mixed with $2 \mu \mathrm{L}$ of buffer containing a reducing agent, in our case, $\beta$-mercapto-ethanol). The supplied samples and kit scale were then denatured for $5 \mathrm{~min}$ at $95^{\circ} \mathrm{C}$ and then diluted with $84 \mu \mathrm{L}$ of sterile solution of MilliQ $\mathrm{H}_{2} \mathrm{O}$. After this treatment, the samples and the scale migrated to the CGE chip and were measured immediately. Interpretation of electrophoresis was performed using the manufacturer's Protein 2100 expert (Agilent) test software for peak detection; quantity and quality of protein fractions were detected as follows: a) Protein 80 (peak size scale): 1.60, $3.5,6.50,15.00,28.00,46.00,63.00,95.00 \mathrm{kDa}$; and b) Protein 230 (peak size scale): 4.50, 7.00, 15.00, 28.00, $46.00,63.00,95.00,150.00,240.00 \mathrm{kDa}$. 

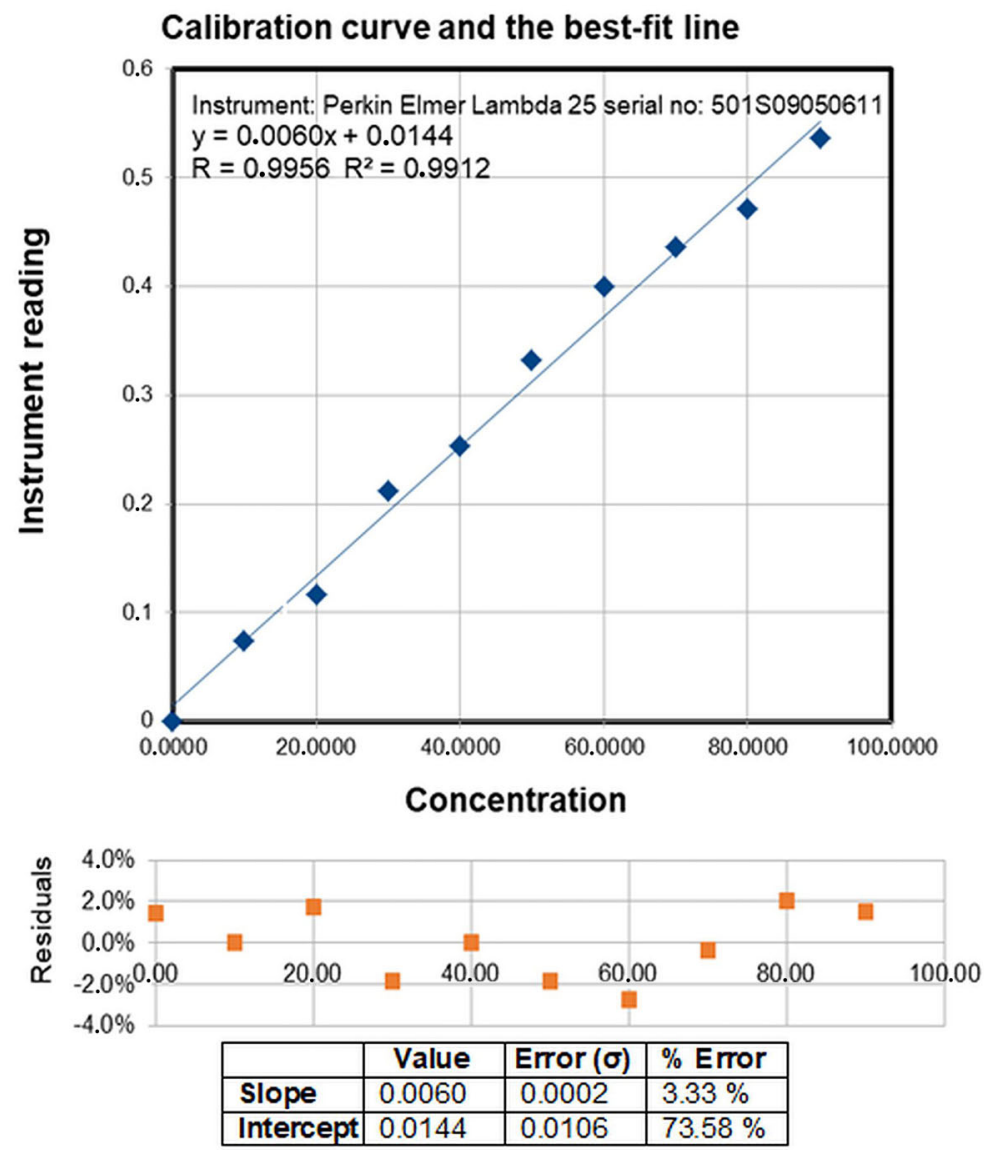

Figure 1. Calibration curve for total protein content in the venom.

\section{Results and Discussion}

\section{Determination of protein content}

The total protein content of the samples was determined according to the known classical methodology originally provided by Lowry in 1951, which was adapted for venom by Dutta et al. (27), the calibration curve being prepared with BSA (Figure 1). The results are reported as percentage of the protein content of the total venom mass as means $\pm S D$ of three analyzes/sample (Table 1).

The values of the electropherograms obtained on the lyophilized venom samples are shown in Figure 2.

Our approach can be classified into the ever-increasing number of preliminary projections for identifying the potential innovative therapeutic tools offered by snake venom. In all of these initial studies, the main objective was to identify with certainty new structures/fractions with possible health benefits (28-30).

The lowest molecular mass molecule determined was observed in interval $6-7 \mathrm{kDa}$ and is related to the presence of non-PLA2 (phospholipase A2) myotoxins that play a role of decreasing the post-envenomation prey trek.
Table 1. Total protein content of freeze-dried venom samples of snake species.

\begin{tabular}{lc}
\hline Snake species & Protein content \\
\hline Crotalus horridus horridus & $92.37 \pm 0.83$ \\
Crotalus molossus nigrescens & $92.03 \pm 0.77$ \\
Crotalus scutulatus salvini & $91.98 \pm 0.52$ \\
Crotalus simus tzabcan & $92.11 \pm 0.94$ \\
Crotalus vegrandis & $91.25 \pm 0.43$ \\
Vipera aspis & $91.24 \pm 0.29$ \\
Vipera bitis arietans & $90.27 \pm 0.42$ \\
Vipera bitis nasicornis & $91.52 \pm 0.38$ \\
Vipera xantina palestinae & $92.01 \pm 0.63$ \\
\hline
\end{tabular}

Data are reported as means \pm SD in percent.

We observed that the Crotalus vegrandis venom contained the highest fraction from the analyzed sample, traces of this compound being detected also in Vipera bitis arietans and Vipera xantina palestinae. 

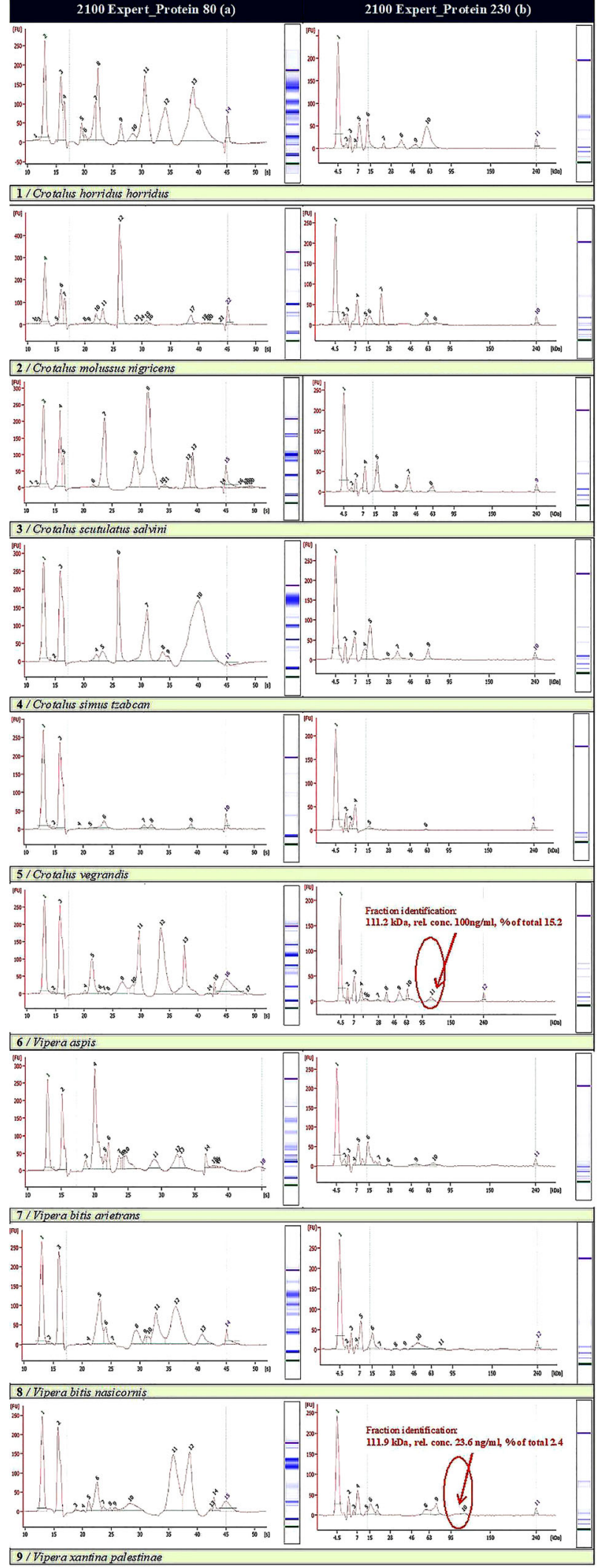

Undoubtedly, this large blend of biochemical molecules present in snake venoms makes these various and complex structures attractive to investigate new therapeutic resources. We have also identified short- and mediumsize disintegrins in the range of 7-10 kDa. Bitistatin and crotatroxin act like disintegrins for $\alpha \mathrm{llb} ; \beta 5$ and $\alpha$ v integrins, with ligands like collagen, fibronectin, vitronectin, fibrinogen, and vitronectin, have known functions in angiogenesis, migration, and invasion processes $(31,32)$.

These molecules are derived from snake venom metalloproteases (SVMP), phylogenetically related with ADAM (a disintegrin and metalloproteinase) and ADAMTS (a disintegrin-like and metalloproteinase with thrombospondin type-1 motifs), extracellular protease enzymes multi-domain family also present in venom. These proteins have the capacity to interact with specific integrins and inhibition of their activity has led to the discovery of potential diagnostic and therapeutic agents in oncology (32).

Phospholipase A, identified by us with the molecular mass interval between $12-17 \mathrm{kDa}$, is a $\mathrm{Ca}^{2+}$-dependent enzyme, which hydrolyzes 2-acyl groups from 3-snphosphoglycerides, with pharmacological effects such as myonecrosis, lipid membrane damage, cardiotoxicity, platelet aggregation initiation/inhibition, and post- and presynaptic neurotoxicity. We have identified the PLA2 group II A subgroup in rattle snake and viper venoms, confirming the research of Fox and Serrano (10).

Classification in subgroups is determined by the 49th position amino acid, known to have a crucial role in catalysis. Despite the fact that these enzymes exist mostly as monomers, the molecular mass variation could be the result of aggregates or complexes formed by the covalent or non-covalent interactions between PLA2 and other proteins. The effect of additional protein association is decisive in amplifying the pharmacological effect. This is the specific case of crotoxin and many other crotoxin-like neurotoxins, like "Mojave toxin" from Crotalus scutulatus salvini or vegrandis toxin from Crotalus vegrandis, which can explain the occurrence of $15-17 \mathrm{kDa}$ fractions for this species (in a proportion of 27.3 and $58.3 \%$, respectively) (10).

The Vipera toxins contain a representative of the heterodimeric PLA2 group, identified in the $13-14 \mathrm{kDa}$ molecular mass interval with an occurrence of $15.4 \%$ for Vipera xantina palestinae; it was firstly described by Ovadia (34) and then confirmed by other authors (35-37).

In the range of $21-24 \mathrm{kDa}$, Crotalus molossus nigrescens registered the highest concentration (67.5\%) fraction, separated and described as a proteinase $\mathrm{E}$ with a molecular weight of 21,390 and the following $\mathrm{N}$-terminal amino acid sequence; Phe-Ala-Lys-Arg-Tyr-Val-Glx-LeuVal-Ile-Val-Ala $(4,14)$.

Figure 2. Electropherograms of lyophilized venom samples showing peak detection, and quantity and quality of detected protein fractions: a) Protein 80 and b) Protein 230, using Protein 2100 Expert Testing (Agilent). 
SVMPs are the most abundant toxins in viperid venoms and have evolved from ADAM family members (most likely from ADAM 7, a non-catalytic like metalloprotease, and ADAM 28, a proteolytic metalloprotease with activity on the extracellular matrix) $(9,10,12,33)$.

These are considered multi-domain proteins and are structured in sub-classes also described by other authors $(3,4,10,12,15,18-20,22,34-40)$ as being: $P-I(25-30 \mathrm{kDa})$ with hemorrhagic and/or non-hemorrhagic action, P-lla (30-45 kDa) with hemorrhagic action, P-Ilb (30-45 kDa) inhibition of platelet aggregation, P-III (50-100 kDa) with hemorrhagic, apoptotic, and factor $X$ activation. In $\mathrm{P}-\mathrm{I}$ subclass (P-I SVMPs only), it was observed that the hemorrhagic minimal dose is greater than that described for subclass P-III.

Metalloproteinase P-II c, b1-1 was isolated and characterized from Agkistrodon bilineatus venom. It had no platelet aggregation activity and was determined in $8 \%$ in Agkistrodon bilineatus (30-40 kDa range) (38). In our case, the highest levels of $\mathrm{Zn}$ metalloproteinase P-III were identified in the venom of Crotalus horridus horridus, Vipera aspis, Vipera xantina palestinae, and the highest level $(50.4 \%)$ in the Crotalus simus tzabcan venom.

In the $60-\mathrm{kDa}$ range, the major component (37.1\%) was identified by us in Vipera xantina and to some extent in Vipera aspis, and it could be related to the class of three hemorrhagic factors with intense proteolytic activity, with casein and gelatin substrate already having been described in the literature (36-40).

A less intensive enzyme studied in snake venom is hyaluronidase, with a molecular weight that can reach $110 \mathrm{kDa}$. It has already been isolated in Agkistrodon venom. This appears to provide extracellular matrix fragmentation and systemic toxin diffusion into the bloodstream (38). The largest fraction we identified for hyaluronidase was of 70-80 $\mathrm{kDa},(29.6 \%)$. Despite demonstrating the appearance of all major snake venom components in the 80-LabChip Protein domain, we also performed parallel electropherograms for the 230-LabChip Protein domain. The analysis revealed a

\section{References}

1. Almeida JR, Resende LM, Watanabe RK, Corregari VC, Huancahuire-Vega S, da S Caldeira CA, et al. Snake venom peptides and low mass proteins: molecular tools and therapeutic agents. Curr Med Chem 2017; 24: 3254-3282, doi: $10.2174 / 0929867323666161028155611$.

2. Calvete JJ, Marcinkiewicz C, Monleon D, Esteve V, Celda B, Juarez $P$, et al. Snake venom disintegrins: evolution of structure and function. Toxicon 2005; 45: 1063-1074, doi: 10.1016/j.toxicon.2005.02.024.

3. Mackessy SP. The field of reptile toxinology. Snakes, lizards, and their venoms. In: Handbook of venoms and toxins of reptiles. (Ed. Mackessy S.P.), Boca Raton: Taylor and Francis/CRC Press; USA; 2010. p 3-24. $125-k D a$ molecular weight protein for Vipera aspis that has been described as a pro-coagulant protein. This activity was described as being involved in the reduction of plasma clotting time without any direct activity in the fibrinogen coagulation process $(36,37,39,40)$.

Researchers are fervent in finding new protein sequences with certain biological activity, the potential of snake venoms being undoubtedly ascertained. In the last decade, different types of venomic structures were identified by recognized groups of researchers, their "small steps" in this topic being crucial for today's medical science (Supplementary Table S1).

This preliminary study represents the starting point in the developing method for isolation and characterization of large size proteins in snake venom. In our case, the evidence of compounds with a molecular weight greater than $80 \mathrm{kDa}(111.2$ and $111.9 \mathrm{kDa})$, in the case of Vipera aspis and Vipera xantina palestinae, samples examined on the Protein 230-LabChip electrophoresis chip can be considered a novelty with possible uses in medicine, requiring further approaches by advanced proteomics techniques to confirm the structural features and biological properties.

\section{Supplementary Material}

Click here to view [pdf].

\section{Acknowledgments}

This work was conducted in the frame of the research projects 35PFE - Projects for financing excellence in CDI and internal project No.181/14.01.2016. The freeze-drying of venom samples as well as the identification of venom protein fractions was performed in the Laboratories of the Study of Antioxidants and Molecular Biology (A1c, A2) and Pharmacology - Toxicology (B12) of CLC-HC (Research Laboratory Center, "Horia Cernescu") from our university.

4. Mackessy SP. Phosphodiesterases, ribonucleases and deoxyribonucleases. In: Enzymes from snake venoms. (Ed. Bailey G.S.), Fort Collins: Alaken USA; 1998. p 361-404.

5. Anderson LA, Dufton MJ. Acetylcholinesterases. In: Enzymes from snake venoms (Ed. Bailey G.S.), Fort Collins, Alaken, USA, 1998. p 545-578.

6. Kini RM. Excitement ahead: structure, function and mechanism of snake venom phospholipase $A_{2}$ enzymes. Toxicon 2003; 42: 827-840, doi: 10.1016/j.toxicon.2003. 11.002.

7. Huang P, Mackessy SP. Biochemical characterization of phospholipase A2 (trimorphin) from the venom of the Sonoran Lyre Snake Trimorphodon biscutatus lambda 
(family Colubridae) Toxicon, 2004; 44: 27-36, doi: 10.1016/ j.toxicon.2004.03.027.

8. Mukherjee AK, Mackessy SP. Biochemical and pharmacological properties of a new thrombin-like serine protease (Russelobin) from the venom of Russell's viper Daboia russelii russelii and assessment of its therapeutic potential. Biochim Biophys Acta 2013; 1830: 3476-3488, doi: 10.1016/ j.bbagen.2013.02.007.

9. Chellapandi P. Structural, functional and therapeutic aspects of snake venom metalloproteinases. Mini Rev Org Chem 2014; 11: 28-44, doi: 10.2174/1570193X1101140402100707.

10. Fox JW, Serrano SM. Structural considerations of the snake venom metalloproteinases, key members of the M12 reprolysin family of metalloproteinases. Toxicon 2005; 45: 969-985, doi: 10.1016/j.toxicon.2005.02.012.

11. Calvete JJ, Sanz L, Angulo Y, Lomonte B, Gutiérrez JM. Venoms, venomics, antivenomics. FEBS Lett 2009; 583: 1736-1743, doi: 10.1016/j.febslet.2009.03.029.

12. Kamiguti $A$, Zuzel M, Theakston R. Snake venom metalloproteinases and disintegrins: interactions with cells. Braz $J$ Med Bio Res 1998; 31: 853-862, doi: 10.1590/S0100-879X 1998000700001.

13. Kini RM, Doley R. Structure, function and evolution of threefinger toxins: mini proteins with multiple targets. Toxicon 2010; 56: 855-867, doi: 10.1016/j.toxicon.2010.07.010.

14. Fox JW, Serrano SM. Approaching the golden age of natural product pharmaceuticals from venom libraries: an overview of toxins and toxin-derivatives currently involved in therapeutic or diagnostic applications. Curr Pharma Design 2007; 13: 2927-2934, doi: 10.2174/138161207782023739.

15. Vonk FJ, Jackson K, Doley R, Madaras F, Mirtschin PJ, Vidal N. Snake venom: from fieldwork to the clinic: recent insights into snake biology, together with new technology allowing high-throughput screening of venom, bring new hope for drug discovery. BioEssays 2011; 33: 269-279, doi: 10.1002/bies.201000117.

16. Kereiakes DJ, Kleiman NS, Ambrose J, Cohen M, Rodriguez S, Palabrica T, et al. Randomized, double-blind, placebo-controlled dose-ranging study of tirofiban (MK383) platelet Ilb/Illa blockade in high risk patients undergoing coronary angioplasty. $\mathrm{J} \mathrm{Am} \mathrm{Col} \mathrm{Cardiol} \mathrm{1996;} 27$ : 536-542, doi: 10.1016/0735-1097(95)00500-5.

17. Sánchez EE, Rodríguez-Acosta A, Palomar R, Lucena SE, Bashir S, Soto JG, et al. Colombistatin: a disintegrin isolated from the venom of the South American snake (Bothrops colombiensis) that effectively inhibits platelet aggregation and SK-Mel-28 cell adhesion. Arch Toxicol 2009; 83: 271-279, doi: 10.1007/s00204-008-0358-y.

18. Earl ST, Masci PP, de Jersey J, Lavin MF, Dixon J. Drug development from Australian elapid snake venoms and the Venomics pipeline of candidates for haemostasis: Textilinin1 (Q8008), Haempatch ${ }^{\mathrm{TM}}$ (Q8009) and CoVase ${ }^{\mathrm{TM}}$ (V0801). Toxicon 2012; 59: 456-463, doi: 10.1016/j.toxicon.2010. 12.010.

19. Koh CY, Kini RM. From snake venom toxins to therapeuticscardiovascular examples. Toxicon 2012; 59: 497-506, doi: 10.1016/j.toxicon.2011.03.017.

20. Brown MC, Staniszewska I, Valle LD, Tuszynski GP, Marcinkiewicz C. Angiostatic activity of obtustatin as alpha1 beta1 integrin inhibitor in experimental melanoma growth. Int J Cancer 2008; 123: 2195-2203, doi: 10.1002/ijc.23777.
21. McLane MA, Joerger T, Mahmoud A. Disintegrins in health and disease. Front Biosci 2008; 13: 6617-6637, doi: 10.2741/3177.

22. Swenson S, Costa F, Ernst W, Fujii G, Markland FS. Contortrastatin, a snake venom disintegrin with anti-angiogenic and anti-tumor activity. Pathophysiol Haemost Thromb 2005; 34: 169-176, doi: 10.1159/000092418.

23. Lock B. Venomous snake restraint and handling. J Exot Pet Med 2008; 17: 273-284, doi: 10.1053/j.jepm.2008.07.012.

24. Wilkinson ST. Guide to venomous reptiles in veterinary practice. J Exot Pet Med 2014; 23: 337-346, doi: 10.1053/ j.jepm.2014.07.012.

25. Gaidhani KA, Harwalkar M, Bhambere D, Nirgude PS. Lyophilization/freeze drying-a review. World J Pharm Res, 2015; 4: 516-543.

26. Halassy B, Brgles M, Habjanec L, Balija ML, Kurtović T, Marchetti-Deschmann $\mathrm{M}$, et al. Intraspecies variability in Vipera ammodytes ammodytes venom related to its toxicity and immunogenic potential. Comp Biochem Physiol C Toxicol Pharmacol 2011; 153: 223-230, doi: 10.1016/j.cbpc. 2010.10.007.

27. Dutta S, Chanda A, Kalita B, Islam T, Patra A, Mukherjee AK. Proteomic analysis to unravel the complex venom proteome of eastern India Naja naja: correlation of venom composition with its biochemical and pharmacological properties. J Proteomics 2017; 156: 29-39, doi: 10.1016/ j.jprot.2016.12.018.

28. Nirthanan S, Gwee MC. Three-finger neurotoxins and the nicotinic acetylcholine receptor, forty years on. J Pharmacol Sci 2004; 94: 1-17, doi: 10.1254/jphs.94.1.

29. Samy RP, Manikandan J, Sethi G, Franco OL, Okonkwo JC, Stiles BG, et al. Snake venom proteins: development into antimicrobial and wound healing agents. Mini Rev Org Chem 2014; 11: 4-14, doi: 10.2174/1570193X1101140402100131.

30. Arruda Macêdo JK, Fox JW, de Souza Castro M. Disintegrins from snake venoms and their applications in cancer research and therapy. Curr Protein Pept Sci 2015; 16: 532-548, doi: 10.2174/1389203716666150515125002.

31. Calvete JJ, Schrader M, Raida M, McLane MA, Romero A, Niewiarowski S. The disulphide bond pattern of bitistatin, a disintegrin isolated from the venom of the viper Bitis arietans. FEBS Lett 1997; 416: 197-202, doi: 10.1016/ S0014-5793(97)01203-9.

32. Lucena S, Sanchez EE, Perez JC. Anti-metastatic activity of the recombinant disintegrin, r-mojastin 1, from the Mohave rattlesnake. Toxicon 2011; 57: 794-802, doi: 10.1016/j. toxicon.2011.02.014.

33. Takeda S. ADAM and ADAMTS Family proteins and snake venom metalloproteinases: a structural overview. Toxins (Basel) 2016; 8: pii: E155.

34. Ovadia M. Isolation and characterization of three hemorrhagic factors from the venom of Vipera palaestinae. Toxicon, 1978; 16: 479-487, doi: 10.1016/0041-0101(78)90145-9.

35. Momic T, Arlinghaus FT, Arien-Zakay H, Katzhendler J, Eble JA, Marcinkiewicz C, et al. Pharmacological aspects of Vipera xantina palestinae venom. Toxins (Basel) 2011; 3: 1420-1432, doi: $10.3390 /$ toxins 3111420

36. Brown MC, Calvete JJ, Staniszewska I, Walsh EM, PerezLiz G, Del Valle L, et al. VEGF-related protein isolated from Vipera palestinae venom, promotes angiogenesis. Growth Factors 2007; 25: 108-117, doi: 10.1080/0897719070153 2385. 
37. Nakar O, Ovadia M, Kochva E. Isolation and characterization of a proteolytic factor from the venom of Vipera palaestinae. Toxicon 1986; 24: 293-304, doi: 10.1016/ 0041-0101(86)90154-6.

38. Nikai T, Taniguchi K, Komori Y, Masuda K, Fox JW, Sugihara $\mathrm{H}$. Primary structure and functional characterization of bilitoxin-1, a novel dimeric P-II snake venom metalloproteinase from Agkistrodon bilineatus venom. Arch Biochem Biophys 2000; 378: 6-15, doi: 10.1006/abbi.2000.1795.
39. Komori Y, Nikai T, Sugihara $\mathrm{H}$. Isolation and characterization of procoagulant from the venom of Vipera aspis aspis. Int $J$ Biochem 1993; 25: 761-767, doi: 10.1016/0020-711X(93) 90363-J.

40. Jan V, Maroun RC, Robbe-Vincent A, De Haro L, Choumet $V$. Toxicity evolution of Vipera aspis aspis venom: identification and molecular modeling of a novel phospholipase A2 heterodimer neurotoxin. FEBS Lett 2002; 527: 263-268, doi: 10.1016/S0014-5793(02)03205-2. 